\title{
Performance, Carcass Traits and Meat Quality Evaluation of Sheep Fed Diets Containing Napier Grass and Graded Levels of Cocoa Pod Husk with Soursop Pulp Meals
}

\author{
M. I. Okoruwa (Correspondence author) \\ Department of Animal Science, Ambrose Alli University, \\ P.M.B. 14, Ekpoma, Edo State, Nigeria \\ Email: odionokos@yahoo.com
}

D. O. Okunlola

Department of Animal Nutrition and Biotechnology,

Ladoke Akintola University of Technology, P.M.B. 4000, Ogbomoso,

Oyo State, Nigeria

Received: December 7, 2016

Accepted: April 14, 2017

Published: June 1, 2017

doi:10.5296/jas.v5i2.11325

URL: https://doi.org/10.5296/jas.v5i2.11325

\begin{abstract}
This study was conducted to determine performance, carcass traits and meat quality evaluation of sheep fed napier grass and different proportion of cocoa pod husk and soursop pulp meals. Eighteen (18) West African Dwarf rams, aged between 7 and 8 months old with mean weight of $7.00 \pm 0.55 \mathrm{~kg}$ were allotted to three dietary treatments with two replicates of three sheep per treatment in a completely randomized design. The compared treatment diets were; $\mathrm{T}_{\mathrm{A}}\left(70 \%\right.$ napier grass and $30 \%$ concentrate diet), $\mathrm{T}_{\mathrm{B}}$ (45\% cocoa pod husk with $25 \%$ soursop pulp and $30 \%$ concentrate diet) and $\mathrm{T}_{\mathrm{C}}(50 \%$ cocoa pod husk with $20 \%$ soursop pulp and $30 \%$ concentrate diet). The experimental diets were given to the sheep at $6 \%$ of their body weight and the experiment lasted for 84days after 14days of adjustment period. The results showed that average daily feed intake $(221.79 \mathrm{~g})$, nitrogen intake $(18.02 \mathrm{~g} /$ day $)$, total nitrogen loss (5.08g/day) and chilling losses $(12.85 \%)$ were significantly $(\mathrm{P}<0.05)$ higher in diet $\mathrm{T}_{\mathrm{A}}$ compared with diets $\mathrm{T}_{\mathrm{B}}$ and $\mathrm{T}_{\mathrm{C}}$. Treatment diet $\mathrm{T}_{\mathrm{C}}$ was significantly $(\mathrm{P}<0.05)$ better
\end{abstract}


in total body weight gain $(3.66 \mathrm{~kg})$, average daily weight gain $(43.57 \mathrm{~g})$, total digestible nutrient $(74.69 \%)$, nitrogen retention $(77.58 \%$, slaughter weight $(11.02 \mathrm{~kg})$, hot carcass weight $(5.68 \mathrm{~kg})$, cold carcass yields $(5.23 \mathrm{~kg})$, hot with cold carcass yields $(51.54$ and $47.46 \%)$, appearance (6.81), tenderness (6.20) and overall acceptability (6.85) than other treatment diets. Initial body weight, flavor and juiciness were not significantly (P >0.05) affected by the treatment diets. It was concluded that $50 \%$ cocoa pod husk with $20 \%$ soursop pulp and $30 \%$ concentrate diet has the potential to enhance performance, carcass traits and meat quality evaluation in sheep.

Keywords: performance, carcass, meat quality, agro-industrial by-products, sheep

\section{Introduction}

Availability of animal protein intake to the human populace especially in the developing countries is becoming a mirage due to dwindling resources and high cost feed components. Most feeds are generally deficient in essential nutrient during the dry season as a result, they cannot support adequate level of ruminant production in the tropics. This makes sheep producers to face huge challenges with inadequate feed supply for their sheep sustainability. The fluctuating quantity and quality of year round forage supply and the greater pressures mounted by other livestock for the available feedstuffs are the major reasons for this critical feeds shortage (Ajayi et al., 2005). This scenario often reduces sheep performance, productivity and increases their mortality. Thus, sheep producers are interested in reducing the pressures on feed scarcity by looking towards alternative feed resources that are readily available, cheaper and under - utilized by livestock farmers.

However, the use of fruit by-products is important in this regards. Fruit by-products have been recognized for many years on their most abundant potential sources of nutrient because of their ability to provide nutrients from a wide range of unlimited primary materials (Okoruwa and Igene, 2014). The application of cocoa (Theobrama cacao) pod husk and soursop (Annona muricata) pulp as feed sources alongside with other strategies may have the potential to increase forage support and reduce the pressure on the expensive common feed ingredients for sheep (Denon et al., 2013; Babajide and Emiola, 2013). They contribute to keeping feed availability all year period and possible to maintain sheep flow which can go a long way in strengthening the productive chain of sheep. Hence, this will offer continuity on sheep production to get a positive high impact on their performance and meat quality in the market. Laye et al. (2014) found that nutritional management of sheep is extremely important for measuring performance and quality of meat production. Notwithstanding, there is still no sufficient published information about the potential use of cocoa pod husk with soursop pulp meal on performance and meat production in sheep. The objective of this study therefore is to determine the performance, carcass traits and meat quality of sheep fed diets containing napier grass and varying levels of cocoa pod husk and soursop pulp meals.

\section{Materials and Methods}

\subsection{Experimental Location}

The experiment was conducted at the Livestock Section of the Teaching and Research Farm, 
Ambrose Alli University, Ekpoma Nigeria. The Farm location is between latitude $6.42^{\circ} \mathrm{N}$ and longitude $6.09^{0} \mathrm{E}$ with a unimodal rainfall pattern which starts from April and end in October. The area has a prevailing tropical climate with mean rainfall and temperature of about $1556 \mathrm{~mm}$ and $31^{\circ} \mathrm{C}$ respectively. Ekpoma is within the South - South geo-political zone of Nigeria.

\subsection{Preparation of the Experimental Diets}

Ripe cocoa pods were obtained from the plantation within Ekpoma and cracked open to remove the cocoa bean together with the placenta. The cocoa pods were then chopped into slices (average sized $5 \mathrm{~cm}$ ), sun-dried before crushed into cocoa pod husk. Fresh ripe soursop fruits were got from a farm in Ekpoma metropolis and identified in herbarium of the department of Botany, Ambrose Alli University, Ekpoma. The peels were removed from the fruits. Thereafter, the juices were extracted from the pulp and the pulps were then dried and crushed into meal. Napier grass (Pennisetum purpureum) was obtained within the Teaching and Research Farm. They were rinsed with water to remove all attached dust and allowed to wilt overnight before being chopped manually using cutlass to a length of approximately $5 \mathrm{~cm}$. the concentrate ingredients that comprised $78 \%$ wheat offal, $20 \%$ dried brewery grain, $0.75 \%$ limestone, $0.50 \%$ bone meal, $0.50 \%$ vitamin premix and $0.25 \%$ salt was formulated and added to the diets.

However, three experimental diets that were prepared consisted of diet $\mathrm{T}_{\mathrm{A}}(70 \%$ of napier grass and $30 \%$ concentrate diet), $\mathrm{T}_{\mathrm{B}}$ (combination of $45 \%$ cocoa pod husk with $25 \%$ of soursop pulp and $30 \%$ concentrate diet) and $\mathrm{T}_{\mathrm{C}}$ (mixture of $50 \%$ cocoa pod husk with $20 \%$ soursop pulp and $30 \%$ concentrate diet).

\subsection{Experimental Animals and their Management}

Eighteen West African Dwarf rams that were sourced from livestock market at ekpoma were used for the study. The rams were about $7-8$ months old with a mean body weight of $7.00 \pm$ $0.55 \mathrm{~kg}$. They were randomly distributed to the three dietary treatments with two replicates of three rams per treatment in a completely randomized design.

Sheep pens were cleaned and disinfected before the arrival of the animals. They were vaccinated against diseases at the commencement of the experimental study. The sheep were housed in individual dwarf wall pen with feeders and drinkers on the concreted floors. Diets were offered at $6 \%$ of their body weight to the sheep once daily at about $8.00 \mathrm{am}$ in the morning in form of compete mixing and ensured voluntary consumption. The rams also had unrestricted access to clean fresh water. The study lasted for 84days after 14day adaptation period.

Live body weight of sheep was measured prior to feeding using a spring balance on weekly basis to determine change in body weight. Total body weight gain was calculated as the difference between the final and initial weight of each sheep. The quantity of the experimental diets offered to sheep and leftovers were also weighed daily in the morning prior to feeding to compute daily feed intake. 


\subsection{Total Digestible Nutrient and Nitrogen Utilization}

At the end of the $10^{\text {th }}$ week of the body weight gain measurement, four rams from each treatment group (totaling 16) were randomly selected for these studies. The sheep were then transferred to individual metabolic cages with slated floors adapted for urine and faecal collection. Sheep were fed with their weighed treatment diets for 14days, seven days for adaptation to the metabolic cages and seven days for collection of samples. The quantity of feeds offered which represented the fraction of the feed given to each sheep was weighed daily. The leftover feeds were also collected and weighed daily. Faecal and urinary collections were measured and recorded daily. Subsequently, they formed daily composite sample per sheep which at the end of the metabolic trial formed a total composite sample per ram per diet. However, sampled treatment diets were stored separately in air tight containers while sampled faecal and urine were stored in a freezer until they were required for analysis.

Total digestible nutrients (TDN) were estimated according to this equation (NRC, 2007). $\mathrm{TDN}=\mathrm{NFcd}+\mathrm{CPd}+($ FAD $\times 2.25)+\mathrm{NDFapd}-7.7$ and the value of metabolic faecal TDN or used to fix and feed digestible fractions used to calculate. TDN refers to true digestibility; NFcd is digestible non-fibre carbohydrates: CPd is digestible crude protein: FAD is digestible fatty acids: NDFapd is NDF corrected for digestible ash and protein.

The chemical composition of the experimental diets with faecal samples and total nitrogen from urinary samples that were stored with $20 \%$ dilute tetraoxosulphate (IV) acid were determined (AOAC, 1990; Van Soest et al., 1991). Thereafter, nitrogen balance of sheep was calculated as the difference between nitrogen intake and nitrogen excreted from faeces and urine, while nitrogen retention in the sheep was computed from nitrogen balance expressed as the percentage of total nitrogen intake.

\subsection{Slaughtering, Processing of Carcass and Sensory Evaluation}

After 84 days of confinement of sheep on their respective pens, they were subjected to solid fasting for 16hours. Thereafter, sheep were randomized in slaughter order and weighed to obtained slaughter weight (SW) before they were slaughtered. After bleeding, the skin, head and limbs were removed before the carcass was eviscerated. The hot carcass weight (HCW) were obtained before the carcasses were conducted to the cold chamber (average $4^{0} \mathrm{C}$ ) for 24hours cooling to obtained cold carcass weight (CCW) and chilling losses (CL) was quantified using the formula (Maciel et al., 2015);

$$
\mathrm{CL}(\%)=\frac{(\mathrm{HCW}-\mathrm{CCW})}{\mathrm{HCW}} \times 100
$$

However, hot carcass yield (HCY) and cold carcass yield (CCY) were computed using the following formulas (Urbano et al., 2013);

$$
\operatorname{HCY}(\%)=\frac{\mathrm{HCW}}{\mathrm{SW}} \times \frac{100}{1}
$$


and

$$
\operatorname{CCY}(\%)=\frac{\mathrm{CCW}}{\mathrm{SW}} \times \frac{100}{1}
$$

However, cooked meat from loin chops were served in plates to a 12 member taste panel drawn from the staff and students population of the department to adjudge the test for appearance, flavor, tenderness, juiciness and overall acceptability of meat samples on a 9 point hedonic scale where (1) corresponds to extremely dislike and (9) to extremely like. Semi training was given to panelists before commencing the test and was supplied with cracker biscuits and water in between the samples (Eniolorunda et al., 2010).

\subsection{Chemical and Statistical Analysis}

The proximate composition of napier grass, cocoa pod husk, soursop pulp and concentrate diet used in this study were analysed according to the procedure of AOAC (1990).

Data collected from performance, carcass traits and meat quality were subjected to analysis of variance (ANOVA) and significant difference between means were separated using Duncan's multiple range test (SAS, 1999).

\section{Results and Discussion}

Table 1. Proximate composition (\%) of napier grass, cocoa pod husk, soursop pulp and concentrate diet.

\begin{tabular}{|l|l|l|l|l|}
\hline & Napier & Cocoa pod & Soursop & Concentrate \\
Nutrients & grass & pusk & 69.89 & 86.48 \\
\hline Dry matter & 74.11 & 70.11 & 3.88 & 20.03 \\
\hline Crude protein & 8.10 & 7.69 & 1.63 & 1.09 \\
\hline Ether extract & 1.14 & 3.85 & 24.32 & 14.01 \\
\hline Crude fibre & 29.57 & 28.97 & 6.99 & 56.92 \\
\hline Ash & 9.95 & 9.81 & & \\
\hline Nitrogen & 51.24 & 49.68 & & \\
\hline extract & & & & \\
\hline
\end{tabular}




\section{MlMacrothink}

The proximate composition of the napier grass, cocoa pod husk, soursop pulp and concentrate diet are presented in Table 1. The dry matter values that ranged from 69.89 to $86.48 \%$ were quite high. However, their higher values suggest the ability of the test feeds to accumulate more nutrients with less feed spoilage. The crude protein content of concentrate diet $(20.03 \%)$ was higher than 10 to $12 \%$ crude protein moderate level required by ruminant for minimum growth performance (Gatemby, 2002). Hence concentrate diet that was added to the crude protein content of napier grass $(8.10 \%)$, cocoa pod husk (7.69\%) and soursop pulp $(3.88 \%)$ was to augment nutrient composition of the test feeds. The ether extract values that varied from $1.09 \%$ in concentrate diet to $3.85 \%$ in cocoa pod husk explained the higher content of fats and oil produced by cocoa pod husk than other test feed ingredients. Moreover, the higher value of crude fibre observed in napier grass (29.57\%), cocoa pod husk $(28.97 \%)$ and soursop pulp (24.32\%) compared with concentrate diet (14.01\%) could be as a result of crude protein that was moderately low in their values as observed in Table 1. The percentage of ash values that ranged between 2.29 and $9.95 \%$ was highest in napier grass and lowest in soursop pulp. This is in line with the report of Ajayi et al. (2005) that grass is a good source of mineral than some agro-industrial by-products. The nitrogen free extract values obtained in soursop pulp $(67.88 \%)$ concentrate diet $(56.92 \%)$ and napier grass $(51.24 \%)$ were relatively better than the value recorded in cocoa pod husk $(49.68 \%)$. The proximate composition values recorded in soursop pulp in this study were similar to the values reported by Degnon $e t$ al. (2013).

Table 2. Growth performance, total digestible nutrient and nitrogen retention in sheep fed experimental diets

\begin{tabular}{|l|c|c|c|c|}
\hline \multirow{2}{*}{ Parameters } & \multicolumn{2}{|c|}{ Treatment diets } & \\
\cline { 2 - 5 } & $\mathrm{T}_{\mathrm{A}}$ & $\mathrm{T}_{\mathrm{B}}$ & \multicolumn{1}{|c|}{$\mathrm{T}_{\mathrm{C}}$} & SEM \pm \\
\hline Initial body weight $(\mathrm{kg})$ & 7.83 & 7.57 & 7.36 & 0.16 \\
\hline Total weight gain $(\mathrm{kg})$ & $2.15^{\mathrm{b}}$ & $3.06^{\mathrm{a}}$ & $3.66^{\mathrm{a}}$ & 0.25 \\
\hline Average daily weight gain $(\mathrm{g})$ & $25.60^{\mathrm{b}}$ & $36.43^{\mathrm{a}}$ & $43.57^{\mathrm{a}}$ & 0.35 \\
\hline Average daily feed intake (g) & $221.79^{\mathrm{a}}$ & $207.38^{\mathrm{b}}$ & $202.74^{\mathrm{c}}$ & 1.98 \\
\hline Total digestible nutrient $(\%)$ & $67.84^{\mathrm{c}}$ & $70.99^{\mathrm{b}}$ & $74.69^{\mathrm{a}}$ & 1.02 \\
\hline Nitrogen intake (g/day) & $18.02^{\mathrm{a}}$ & $16.96^{\mathrm{b}}$ & $17.04^{\mathrm{b}}$ & 0.92 \\
\hline
\end{tabular}




\begin{tabular}{|c|c|c|c|c|}
\hline Total nitrogen loss (g/day) & $5.08^{\mathrm{a}}$ & $4.02 \mathrm{~b}$ & $3.82 \mathrm{~b}$ & 0.83 \\
\hline Nitrogen retention (\%) & $71.81^{\mathrm{b}}$ & $76.30^{\mathrm{a}}$ & $77.58^{\mathrm{a}}$ & 0.37 \\
\hline
\end{tabular}

${ }^{\text {abc }}$ Means within rows with unlike superscripts are significantly different from each other $(\mathrm{P}<0.05)$

The numerical values of initial body weight that ranged between 7.36 and $7.83 \mathrm{~kg}$ were not significantly $(\mathrm{P}>0.05)$ affected. This implies that the sheep were almost having the same weight at the commencement of the experiment. The sheep fed diet $\mathrm{T}_{\mathrm{B}}(3.06 \mathrm{~kg})$ gave similar significant $(\mathrm{P}>0.05)$ values of total body weight gain as those fed diet $\mathrm{T}_{\mathrm{C}}(3.66 \mathrm{~kg})$ but they were significantly higher $(\mathrm{P}<0.05)$ than sheep fed diet $\mathrm{T}_{\mathrm{A}}(2.15 \mathrm{~kg})$. The average daily weight gain values of $25.60,36.43$ and $43.57 \mathrm{~g}$ that were obtained for sheep in treatment diets $\mathrm{T}_{\mathrm{A}}, \mathrm{T}_{\mathrm{B}}$ and $\mathrm{T}_{\mathrm{C}}$ respectively followed the same sequence as in total body weight gain. However, the significant $(\mathrm{P}<0.05)$ reduction in total body and average daily weight gains of sheep fed $70 \%$ napier grass with $30 \%$ concentrates $\left(\mathrm{T}_{\mathrm{A}}\right)$ compared with sheep fed varying levels of cocoa pod husk with soursop pulp and $30 \%$ concentrate diets $\left(\mathrm{T}_{\mathrm{B}}\right.$ and $\left.\mathrm{T}_{\mathrm{C}}\right)$ could be ascribed to the inferiority exhibited by the diet that led to poor nutrient retention and utilization. This is in agreement with the report of Kalio et al. (2013) who found that improper balancing of ingredients in the treatment diets have negative effect on the nutritional level and growth performance of the animals. There was significant $(\mathrm{P}<0.05)$ difference across the treatment means for average daily feed intake. The sheep placed on $\mathrm{T}_{\mathrm{A}}$ $(221.79 \mathrm{~g})$ recorded the highest value, followed by $\mathrm{T}_{\mathrm{B}}(207.38 \mathrm{~g})$ before $\mathrm{T}_{\mathrm{C}}(202.74 \mathrm{~g})$ that was the lowest. This disparity in values of feed intake could be explained as the rate of the sheep consuming the diets to meet up or satisfy their nutrient requirements for their nutrient requirements for their growth performance. This confirms the findings of Ajayi et al., (2005) who reported that the levels of fibre combination in diets of ruminant animals interfered with their nutritional requirement and uptake of nutrient for their performance.

Digestible nutrient intake is a function of apparent nutrient digestibility and dry matter intake. The higher significant $(\mathrm{P}<0.05)$ values obtained in sheep fed $\mathrm{T}_{\mathrm{C}}(74.69 \%)$, followed by $\mathrm{T}_{\mathrm{B}}$ (70.99\%) before $\mathrm{T}_{\mathrm{A}}(67.24 \%)$ could be the consequence of its level of apparent nutrient digestibility and energy concentration relative to the nutrient components of the diets. However, the highest value of total digestible nutrient recorded in $T_{C}$ compared with $T_{B}$ and $\mathrm{T}_{\mathrm{C}}$ indicated that the diet could produced enough digestible energy per unit of digestible crude protein for optimization of feed utilization. Olafadehan et al. (2014) earlier attributed that higher total digestible nutrient from digestible energy per unit of digestible crude protein is required for optimum feed utilization.

The ability to manipulate nitrogen intake in ruminant has important environmental and nutritional applications. The nitrogen intake that ranged between 16.96 and $18.02 \mathrm{~g} / \mathrm{day}$ varied among treatment diets with sheep on $\mathrm{T}_{\mathrm{A}}$ significantly higher than those on $\mathrm{T}_{\mathrm{B}}$ and $\mathrm{T}_{\mathrm{C}}$. This variation in nitrogen intake could probably be in connection with the relative amount of the diet consumed. Total nitrogen loss in sheep on $\mathrm{T}_{\mathrm{B}}(4.02 \mathrm{~g} / \mathrm{day})$ and $\mathrm{T}_{\mathrm{C}}(3.82 \mathrm{~g} / \mathrm{day})$ were 
similar in values and significantly $(\mathrm{P}<0.05)$ lower than the value obtained in $\mathrm{T}_{\mathrm{A}}(5.08 \mathrm{~g} / \mathrm{day})$. It appears that combination of cocoa pod husk with soursop pulp meals help in improving nitrogen metabolism in the rumen which possibly accounts for reduction in urinary and faecal nitrogen excreted. Agle et al. (2010) reported that higher total nitrogen loss (urinary and faecal) in diet could be due to rapid degradation of the diet by rumen microbes to produce excess ammonia nitrogen which is absorbed and excreted in the form of urinary and faecal nitrogen loss. In the same view, Okoruwa and Igene (2014) found that nitrogen excreted in urine will depend on urea recycling and the efficiency of utilization of ammonia produced in the rumen by microbes for protein synthesis. Hence, decreasing nitrogen excretion in ruminants could result in positive and effective performance of animals.

Feeding sheep on high ruminally degradable protein sources might increase nitrogen retention. Thus, strategic of feeding protein diets to ruminant might positively influence the retention of nitrogen in sheep. Olafadehan et al. (2014) found that nitrogen retention depends on the intake of nitrogen and the amount of fermentable carbohydrate of the diet. The nitrogen retention values of $71.81,76.30$ and $77.58 \%$ were obtained in $T_{A}, T_{B}$ and $T_{C}$ respectively with sheep on diets $T_{B}$ and $T_{C}$ having higher nitrogen retention and significantly different $(\mathrm{P}<0.05)$ from those in $\mathrm{T}_{\mathrm{A}}$. Okoruwa and Adewumi (2010) reported that if more nitrogen is retained as a percentage of total nitrogen fed, more protein would be available to maximize growth and production in the sheep.

Table 3, summarizes data on carcass traits and sensory evaluation of sheep fed experimental diets. The slaughter weight values of $9.98,10.62$ and $11.02 \mathrm{~kg}$ were obtained in sheep placed on $T_{A}, T_{B}$ and $T_{C}$ respectively, with sheep on $T_{B}$ and $T_{C}$ significantly $(P<0.05)$ higher than $\mathrm{T}_{\mathrm{A}}$. The likely mechanism explaining this variation could be the level of nutrient utilization and retention that interfered with the weight of sheep. This implies that when cocoa pod husk and soursop pulp are properly fed in appropriate proportions might become an important source of nutrients in sheep feeding that provide satisfactory performance in terms of weight gain.

Table 3. Carcass characteristics and sensory evaluation of sheep fed napier grass and graded levels of cocoa pod husk with soursop pulp meals.

\begin{tabular}{|l|c|c|c|c|}
\hline \multirow{2}{*}{ Parameters } & \multicolumn{2}{|c|}{ Treatment diets } & \multirow{2}{*}{ SEM \pm} \\
\cline { 2 - 4 } & $\mathrm{T}_{\mathrm{A}}$ & $\mathrm{T}_{\mathrm{B}}$ & \multicolumn{1}{|c|}{$\mathrm{T}_{\mathrm{C}}$} & \\
\hline Carcass characteristics & & & & \\
\hline Slaughter weight $(\mathrm{kg})$ & $9.98^{\mathrm{b}}$ & $10.63^{\mathrm{a}}$ & $11.02^{\mathrm{a}}$ & 0.07 \\
\hline Hot carcass weight $(\mathrm{kg})$ & $4.98^{\mathrm{b}}$ & $5.43^{\mathrm{a}}$ & $5.68^{\mathrm{a}}$ & 1.32 \\
\hline
\end{tabular}




\begin{tabular}{|l|r|r|r|c|}
\hline Cold carcass weight (kg) & $4.34^{\mathrm{b}}$ & $4.99^{\mathrm{b}}$ & $5.23^{\mathrm{a}}$ & 0.14 \\
\hline Chilling losses (\%) & $12.85^{\mathrm{a}}$ & $9.10^{\mathrm{b}}$ & $7.92^{\mathrm{c}}$ & 0.62 \\
\hline Hot carcass yield (\%) & $49.90^{\mathrm{b}}$ & $51.08^{\mathrm{a}}$ & $51.54^{\mathrm{a}}$ & 1.21 \\
\hline Cold carcass yield (\%) & $43.49^{\mathrm{b}}$ & $46.94^{\mathrm{a}}$ & $47.46^{\mathrm{a}}$ & 0.11 \\
\hline Sensory evaluation & & & & \\
\hline Appearance & & & & 0.38 \\
\hline Flavour & $5.17^{\mathrm{b}}$ & $6.21^{\mathrm{a}}$ & $6.81^{\mathrm{a}}$ & 0.52 \\
\hline Tenderness & 6.38 & 6.68 & 6.97 & 0.25 \\
\hline Juiciness & $5.99^{\mathrm{b}}$ & $6.11^{\mathrm{a}}$ & $6.20^{\mathrm{a}}$ & 0.40 \\
\hline Overall acceptability & $5.28^{\mathrm{b}}$ & $6.52^{\mathrm{a}}$ & $6.85^{\mathrm{a}}$ & 0.59 \\
\hline
\end{tabular}

${ }^{a b c}$ Means with different superscripts along the same row are significantly different $(P<0.05)$. $\mathrm{SEM} \pm=$ standard error of mean

Hot and cold carcass weights were significantly $(\mathrm{P}<0.05)$ lower in sheep placed on diet $\mathrm{T}_{\mathrm{A}}$ (4.98 and $4.34 \mathrm{~kg})$ compared with sheep on diets $\mathrm{T}_{\mathrm{B}}(4.43$ and $4.99 \mathrm{~kg})$ and $\mathrm{T}_{\mathrm{C}}(5.68$ and $5.23 \mathrm{~kg}$ ). The marked reduction for slaughter weight in sheep on diet $\mathrm{T}_{\mathrm{A}}$ might explain the decreased observed for hot and cold carcass weights, given the direct implication that they were actually marked low in nutrient retention (Galvani et al., 2014). Chilling losses were explained by some researchers (Lage et al., 2014; Maciel et al., 2015) as the weight different after carcass cooling. The chilling losses among sheep on diet $\mathrm{T}_{\mathrm{A}}(12.85 \%)$ were significantly $(\mathrm{P}<0.05)$ higher, followed by $\mathrm{T}_{\mathrm{B}}(9.10 \%)$ before $\mathrm{T}_{\mathrm{C}}(7.92 \%)$ which was the least. This disparity in values obtained in chilling losses could be trailed to variation in fat deposition between individual carcass and chemical reactions in the muscles. The values obtained for hot and cold carcass yields were also significantly $(\mathrm{P}<0.05)$ better in carcasses from sheep placed on $\mathrm{T}_{\mathrm{C}}(51.54$ and $47.46 \%)$ and $\mathrm{T}_{\mathrm{B}}(51.08$ and $46.94 \%)$ compared with those on $\mathrm{T}_{\mathrm{A}}$ (49.90 and 43.49\%). This observation further attest the positive impact of cocoa pod husk with soursop pulp meals on most of the carcass characteristics examined in the study sheep. Thus, the purpose of using alternative feeds in this study, which is to reduce feed scarcity and 
cost do not affect carcass variables negatively but improve the parameters.

The results for sensory evaluation of meat samples from sheep fed napier grass and graded levels of cocoa pod husk with soursop pulp meal are also shown in Table 3. The results indicated that there were no significant $(\mathrm{P}>0.05)$ differences in flavor and juiciness of the sensory variables tested by the panelists. The appearance of meat that ranged between 5.17 and 6.81 was significantly $(\mathrm{P}<0.05)$ highest in diets $\mathrm{T}_{\mathrm{B}}$ and $\mathrm{T}_{\mathrm{C}}$ and lowest in $\mathrm{T}_{\mathrm{A}}$. This implies that the meats from sheep in diet TA were dull in appearance and rated low than those on other treatment diets. Tenderness of meat samples from sheep fed treatment diets $\mathrm{T}_{\mathrm{C}}(6.20)$ and $T_{B}(6.11)$ were significantly $(P<0.05)$ preferred to sheep placed on $T_{A}$ (5.99). The overall acceptability of the meat samples from sheep on diets $T_{C}(6.85)>T_{B}(6.52)$ in that order were highly accepted $(\mathrm{P}<0.05)$ compared with diet $\mathrm{T}_{\mathrm{A}}(5.82)$ that was the least accepted by the taste of panelist. Though the statistical values obtained from flavor and juiciness were not significantly $(\mathrm{P}>0.05)$ affected by treatment diets, there numerical values that ranged from 6.38 to 6.97 and 5.82 to 6.85 respectively, were better in meat samples from sheep fed diet $T_{C}$, closely followed by those on $T_{B}$ before $T_{A}$ in that order of ranking. This implies that the varying levels of cocoa pod husk with soursop pulp inclusion in the dietary treatments did not affect the sensory properties of the meat samples from sheep adversely. Notwithstanding, this observation correspond with the report of Eniolorunda et al. (2010) who found no significant $(\mathrm{P}>0.05)$ different in feeding varying levels of biscuit waste meal to rams on some of the sensory (flavour and juiciness) variables.

\section{Conclusion and Recommendation}

This study supports the notion that agro-industrial by-products are excellent sources of alternative feeds in sheep nutrition, which can be used as basal diets at least cost of production and benefits accruable to farmers without compromising any negative effect on the performance and meat quality. It is therefore expected that such alternative feeds would help in making animal protein available and affordable to an average Nigerian and at the same time reducing the competition between man and livestock for feeds.

The results from the study showed that sheep fed graded levels of cocoa pod husk with soursop pulp meals compared favourably than the sheep fed on napier grass. Thus, sheep performance, carcass traits and meat quality evaluation measured were better in sheep fed on mixture of $50 \%$ cocoa pod husk with $20 \%$ soursop pulp and $30 \%$ concentrate diet than other diets. In general, it was observed that varying levels of cocoa pod husk and soursop pulp meals can be used in replacement of napier grass to improve the performance and meat quality as well as the consumer acceptability of sheep meat.

\section{References}

Agle, M., Hridtov, A. N., Zaman, S., Schneiden, C., Hjegwa, P. M., \& Vaddella, V. K. (2010). Effect of dietary concentrate on rumen fermentation digestibility and nitrogen losses in dairy cows. Journal of dairy Sciences, 93, 4211 - 4222. https://doi.org/10.3168/jds.2009-2977

Ajayi, D. A., Adeneye, J. A., \& Ajayi, F. T. (2005). Intake and nutrient utilization of West Africa Dwarf goats fed mango (Mangifera indica), Ficus (Ficus thionningii), Gliricidia 
(liricidia sepium) foliages and concentrates as supplements to basal diet of guinea grass (Panicum maximum). World Journal of Agricultural Science, 1(2), 184 - 189.

AOAC (1990). Official method of analysis, 15ed. Association of official analytical chemical, Washington. DC. USA., $68-69$.

Babajide, S. E., \& Eniola, L. A. (2013). Performance of laying hens fed different levels of cocoa bean shell. Proceedings of the 4th Nigerian International Poultry Summit, 17 - 21.

Degnon, R. G., Adjou, E. S., Noudogbessi, J. P., Metome, G., Boko, F., Dahouenon - Ahoussi, E, Sonmanou, M. \& Sohounhloue, D. E. K. (2013). Investigation on nutritional potential of soursop (Annona muricata) from Benin for its use as food supplement against protein energy deficiency. International Journal of Biosciences, 3(6), 135 - 144.

https://doi.org/10.12692/ijb/3.6.135-144

Eniolorunda, O. O., Apata, E. S., Badejo, B. B., \& Okubanjo, A. O. (2010). Evaluation of the meat quality of Yankasa rams fed graded levels of biscuit waste. Nigerian Journal of Animal Production, 38(1), 153 - 159.

Galvani, D. B., Pires, C. C., Hubner, C. H. Carvalhos, S. \& Wommer, T. P. (2014). Growth performance and carcass traits of early-weaned lambs as affected by the nutritional regimen of lactating ewes. Small Ruminant Research, 12, 1 - 5.

https://doi.org/10.1016/j.smallrumres.2014.03.008

Gatemby, R. M. (2002). Sheep revised edition. Tropical Agricultural Series. Macmillan Publisiher Ltd. New York NY. Pp $8-9$.

Kalio, G. A., Ayuk, A. A., \& Agwunobi, L. N. (2013). Performance and economics of production of West African Dwarf (WAD) buck fed crop by-products as sole feed in Cross River State, Nigeria. World Science Research Journals, 1(3), 081 - 087.

Lage, J. F., Paulino, P. V. R., Perreira, L. G. R., Duarte, M. S. Valadares Fillho, S. C., (Olivveira, A. S., Souza, N. K. P. \& Lima, J. C. M. (2014). Carcass characteristics of feedlot lambs fed crude glycerin contaminated with high concentrations of crude fat. Meat Science Technology, 96, 108 - 113. https://doi.org/10.1016/j.meatsci.2013.06.020

Maciel, M. V., Carvaliho, F. F.R., Batista. Guim A, Souza, E. J. O., Maciel, L. P. A. A., Pereira - Neto, J. D. \& Lima - Junior, D. M. (2015). Carcass and non - carcass characteristics of sheep fed cassava (Manihot pseudoglaziovii Pax and Hoffm, K.) Chilean Journal of Agricultural Research, 75(3), 307 - 312.

https://doi.org/10.4067/S0718-58392015000400006

NRC (2007). Nutrient requirement of small ruminants: sheep, goats, cervids and new world camelids. 347p. National Research Council (NRC). National Academy of Science. Washington DC. USA.

Okoruwa, M. I., \& Adewumi, M. K. (2010). Effect of replacing Panicum maximum with dried pineapple pulp on nutrient digestibility and nitrogen balance of West Afican Dwarf sheep. Nigerian Journal of Animal Science, 12, 103 - 109. 
https://doi.org/10.9790/2380-07132128

Okoruwa, M. I., \& Igene, F. U. (2014). Comparison of fermentation kinetics (in-vitro) of Napier grass and fruit peels for ruminants: The pattern of organic matter degradability, volatile fatty acid concentration estimated methane and microbial biomass production. Journal of Agriculture and Veterinary Science, 7, 21 - 28.

Olafadehan, O. A., Okunade, S. A., \& Njidda, A. A. (2014). Evaluation of bovine rumen content as a feed ingredient for lambs. Tropical Animal Health and Production, 46, 939 - 945. https://doi.org/10.1007/s11250-014-0590-9

SAS (1999). Statistical Analysis System. SAS User's Guide. Cary, N. Y. SAS Institute.

Urbano, S. A., Ferrererira, M. A., Dutra - Junior, W.M., Xavier de Andrade, R., Bernardo de Sequeira, M. C., \& Felix, S, C. R. (2013). Carcass characteristics of sheep fed with castor bean husk in replacement of tifton 85 hay. Cienc Agrotechnological Lavras, 36(1), 85 - 93. https://doi.org/10.1590/S1413-70542013000100010

Van Soest, P. J., Robertson, J. B., \& Lewis, B. A. (1991). Methods for dietary fibre, neutral detergent fibre and non starch polysaccharide in relation to animal nutrition. Journal of Dairy Science, 74, 3538 - 3597. https://doi.org/10.3168/jds.S0022-0302(91)78551-2

\section{Copyright Disclaimer}

Copyright for this article is retained by the author(s), with first publication rights granted to the journal.

This is an open-access article distributed under the terms and conditions of the Creative Commons Attribution license (http://creativecommons.org/licenses/by/4.0/). 